\title{
Genetic Variability and Heritability for Yield and Yield Attributes in Field Bean (Lablab purpureus L.) Genotypes
}

\author{
S. Sadak Peer, P. Syam Sundar Reddy*, Syed Sadarunnisa, \\ D.S. Reddy and S.R. Pandravada
}

Department of Vegetable Science, College of Horticulture, Dr. Y S R Horticultural University Anantharajupeta, Dr.Y.S.R Kadapa-516105, A.P., India

*Corresponding author

\begin{abstract}
A B S T R A C T
Twenty nine genotypes of Field bean (Lablab purpureus L.) were evaluated to study the genetic variability on yield, yield contributing and related 18 attributes viz.,, days to first flowering, days to 50 per cent flowering, days to first pod set, number of inflorescences

Keywords

Field bean, Variability, Heritability, Genetic advance, GCV and PCV

\section{Article Info}

Accepted:

16 February 2018

Available Online:

10 March 2018 per plant, length of inflorescence $(\mathrm{cm})$, number of pods per inflorescence, length of the pod $(\mathrm{cm})$, width of the pod $(\mathrm{cm})$, days to first pod harvest, days to last pod harvest, weight of 10 green pods $(\mathrm{g})$, number of pods per plant, number of seeds per pod, seed length $(\mathrm{mm})$, seed width $(\mathrm{mm})$, dry seed yield per plant $(\mathrm{g}), 100$ seed weight $(\mathrm{g})$ and fresh pod yield per plant. The range, genotypic and phenotypic coefficient of variation, heritability, genetic advance and correlation were calculated. The genotypes showed considerable amount of variability for all the traits. Wide range of variability was recorded for fresh pod yield per plant, dry seed yield per plant, days to 50 per cent flowering and days to first pod set. On the basis of mean performance, the genotypes, NAIP-BD-ADB-70 and NSJ-186 were found to be superior for almost all the attributes. The genotypic and phenotypic coefficients of variation were high $(>20 \%)$ for fresh pod yield per plant, number of pods per plant and number of inflorescences per plant. The characters viz., number of pods per plant, days to last pod harvest, weight of 10 green pods, dry seed yield per plant and fresh pod yield per plant had high genetic high heritability coupled with high genetic advance and GA as per cent of mean indicating the predominance of additive gene action.
\end{abstract}

\section{Introduction}

Field bean (Lablab purpureus L.) $2 \mathrm{n}=2 \mathrm{x}=22$, 24 is an important legume vegetable grown all over the country for the fleshy and soft textured green pods, which is a good source of proteins, minerals and dietary fibre. The dry seeds are also used for various vegetable preparations and foliage of the crop provides hay, silage and green manures. India is the centre of diversity of Field bean and large numbers of indigenous strains are available in India. Although this crop has originated in India but very little work has been done for the genetic improvement of yield and quality. A great range of variation exists for the plant and pod characters amongst the accessions grown all over the country. The success of 
any breeding programme in general and improvement of specific trait through selection in particular, totally depends upon the genetic variability present in the available germplasm of a particular crop. Since, many of the plant characters are governed by polygenes and greatly influenced by environmental conditions; the progress of breeding is, however, conditioned by the magnitude, nature and interrelationship of genotypic and non-genotypic variation. It is very difficult to judge whether observed variability is heritable or due to environment alone. Moreover knowledge of heritability is essential for selection of superior genotypes.

Genetic improvement in Field bean is a continuous demand for higher yield and yield attributing characters for different agroclimatic regions. Possibility of achieving improvement in any crop plant depends on the magnitude of genetic variability. Improvement of economic characters like yield through selection is conditioned by the nature and magnitude of variability existing in such populations. Genetic parameters such as genotypic coefficient of variation (GCV) and phenotypic coefficient of variation (PCV) are useful in detecting the amount of variability present in the germplasm. Heritability estimates along with genetic advance are more helpful in predicting the genetic gain under selection than heritability estimates alone. It helps in determining the influence of environment on the expression of the genotypic variation and reliability of direct selection for fixation of characters in further generations. Hence, an attempt was made with specific objective to examine the genetic parameters of variability to identify major characters for achieving higher yield.

\section{Materials and Methods}

Twenty nine genotypes of field bean including local check (TFB-1) collected from
NBPGR Regional station, Hyderabad were evaluated in a randomized complete block design with three replications during kharif 2016 at vegetable farm, College of Horticulture, Anantharajupeta, YSR Dist., Andhra Pradesh. Each genotype was planted in single row of $6 \mathrm{~m}$ length with a spacing of $1 \mathrm{~m}$ between rows and $60 \mathrm{~cm}$ between the plants. All the recommended package of practices and plant protection measures were followed timely to raise a good crop. Five plants were randomly taken from each plot to record observations on twenty two yield components except days to first flowering, days to 50 per cent flowering, days to first pod set and 100 seed weight was recorded on whole plot basis.

Analysis of variance was performed following the standard procedure given by Panse and Sukhatme (1967).The phenotypic and genotypic coefficients of variation (PCV, GCV) were computed as per method described by Burton and Devane (1953). Estimates of genotypic and phenotypic correlation were obtained using the formulae given by Lush (1940). Heritability in broad sense and genetic advance (\% of mean) were calculated as per Allard (1960).

\section{Results and Discussion}

Highly significant differences were observed among the genotypes for all the characters indicating presence of sufficient amount of variability in all the characters studied. The mean sum of squares for 18 characters in 28 genotypes and one check variety of dolichos bean were presented in Table 1.

High range was observed for days to $50 \%$ flowering, number of pods per inflorescence, number of inflorescences per plant, duration of harvesting, number of pods per plant, number of seeds per pod, fresh pod yield per plant and dry seed yield per plant (Table 2). A 
variation for these characters is found to be quite high which might be responsible for the wide range in yield potential of different genotypes. A wide range of variation existing for various quantitative traits has also been reported in field bean by Kambale et al., (2002), Ganesh (2005), Lal et al., (2005), Patil and Lad (2007), Rai et al., (2008), Savitha (2008), Chattopadhyay and Dutta (2010) and Verma et al., (2015).

The maximum seed yield (209.48 g) was recorded in the NSJ-186, while the minimum seed yield was recorded in IC-446556 (41.45 g). Eleven genotypes recorded significantly more dry seed yield per plant when compared to grand mean. Five of the genotypes recorded significantly more dry seed yield per plant when compared to the check TFB1(149.68 g). The fresh pod yield per plant ranged from 136.92 to $701.04 \mathrm{~g}$ with a grand mean of $370.92 \mathrm{~g}$. The genotype NAIP-BDADB-70 recorded the maximum marketable pod yield per plant $(701.04 \mathrm{~g})$ and the minimum pod yield (136.92 g) was recorded in IC-446556. Eleven genotypes recorded significantly more marketable pod yield per plant when compared to grand mean. Out of twenty nine genotypes NAIP-BD-ADB-70 and NSJ-186 recorded high fresh pod yield per plant than the commercial check TFB1.Similar pattern of variability in germplasm evaluation of different sizes for various horticultural traits in Dolichos bean have earlier been reported by Baswana et al., (1980) and Borah and Shadeque (1992).

Table.3 Summary of genetic parameters of variability for various characters in twenty nine field bean genotypes

\begin{tabular}{|l|l|c|c|c|c|c|}
\hline $\begin{array}{l}\text { S. } \\
\text { No. }\end{array}$ & Character & $\begin{array}{c}\text { PCV } \\
(\mathbf{\%})\end{array}$ & $\begin{array}{c}\text { GCV } \\
(\mathbf{\%})\end{array}$ & $\begin{array}{c}\text { Heritability } \\
\mathbf{h}^{\mathbf{2}}\end{array}$ & $\begin{array}{c}\text { Genetic } \\
\text { Advance }\end{array}$ & $\begin{array}{c}\text { GA as per } \\
\text { cent of mean }\end{array}$ \\
\hline $\mathbf{1}$ & Days to first flowering & M & M & H & M & H \\
\hline $\mathbf{2}$ & Days to 50 per cent flowering & M & M & H & M & H \\
\hline $\mathbf{3}$ & Days to first pod set & M & M & H & M & H \\
\hline $\mathbf{4}$ & $\begin{array}{l}\text { No. of inflorescences per } \\
\text { plant }\end{array}$ & H & M & H & L & H \\
\hline $\mathbf{5}$ & Length of inflorescence (cm) & H & H & H & M & H \\
\hline $\mathbf{6}$ & No. of pods per inflorescence & H & H & H & L & H \\
\hline $\mathbf{7}$ & Length of the pod (cm) & H & H & H & L & H \\
\hline $\mathbf{8}$ & Width of the pod (cm) & M & M & H & L & H \\
\hline $\mathbf{9}$ & Days to first pod harvest & L & L & H & M & M \\
\hline $\mathbf{1 0}$ & Days to last pod harvest & M & M & H & H & H \\
\hline $\mathbf{1 1}$ & Weight of 10 green pods $(\mathrm{g})$ & H & H & H & H & H \\
\hline $\mathbf{1 2}$ & No. of pods per plant & H & H & H & H & H \\
\hline $\mathbf{1 3}$ & No. of seeds per pod & M & M & H & L & H \\
\hline $\mathbf{1 4}$ & Seed length (mm) & M & L & M & L & L \\
\hline $\mathbf{1 5}$ & Seed width (mm) & M & L & L & L & L \\
\hline $\mathbf{1 6}$ & Dry seed yield per plant $(\mathrm{g})$ & H & H & H & H & H \\
\hline $\mathbf{1 7}$ & 100 seed weight $(\mathrm{g})$ & M & M & H & L & H \\
\hline $\mathbf{1 8}$ & Fresh pod yield per plant $(\mathrm{g})$ & H & H & H & H & H \\
\hline
\end{tabular}


Table.1 Analysis of variance for 18 yield and yield attributes in twenty nine genotypes of field bean

\begin{tabular}{|c|c|c|c|c|}
\hline \multirow[t]{2}{*}{ S.No } & \multirow[t]{2}{*}{ Character } & \multicolumn{3}{|c|}{ Mean sum of squares } \\
\hline & & $\begin{array}{l}\text { Replications } \\
\quad(d \mathbf{d}=2)\end{array}$ & $\begin{array}{l}\text { Treatments } \\
\quad(d f=28)\end{array}$ & $\begin{array}{l}\text { Error } \\
(\mathrm{df}=56)\end{array}$ \\
\hline 1 & Days to first flowering & $237.68 * *$ & $202.78 * *$ & 3.39 \\
\hline 2 & Days to $50 \%$ flowering & $247.72 * *$ & $218.22 * *$ & 3.83 \\
\hline 3 & Days to first pod set & $299.13 * *$ & 230.73 & 4.46 \\
\hline 4 & Number of inflorescences per plant & $24.30 * *$ & $53.64 * *$ & 0.40 \\
\hline 5 & Length of inflorescence (cm) & $32.98 * *$ & $97.53 * *$ & 0.56 \\
\hline 6 & Number of pods per inflorescence & $2.59 * *$ & $12.10 * *$ & 0.03 \\
\hline 7 & Length of the pod $(\mathrm{cm})$ & $0.13 * *$ & $10.95 * *$ & 0.04 \\
\hline 8 & Width of the pod $(\mathrm{cm})$ & 0.02 & $0.16^{* *}$ & 0.01 \\
\hline 9 & Days to first pod harvest & $436.53 * *$ & $257.97 * *$ & 6.09 \\
\hline 10 & Days to last pod harvest & $1141.68 * *$ & $1152.42 * *$ & 15.22 \\
\hline 11 & Weight of 10 green pods & $44.17 * *$ & 371.80 & 1.01 \\
\hline 12 & Number of pods per plant & $1045.30 * *$ & $9193.93 * *$ & 18.67 \\
\hline 13 & Number of seeds per pod & $0.66 * *$ & $0.49 * *$ & 0.01 \\
\hline 14 & Seed length $(\mathrm{mm})$ & 0.53 & $2.74 * *$ & 0.89 \\
\hline 15 & Seed width (mm) & 0.64 & $1.09 * *$ & 0.57 \\
\hline 16 & Dry seed yield per plant (g) & $7678.51 * *$ & $5296.59 * *$ & 106.32 \\
\hline 17 & 100 seed weight (g) & $27.09 * *$ & $45.49 * *$ & 0.40 \\
\hline 18 & Fresh pod yield per plant (g) & $8118.57 * *$ & $87448.48 * *$ & 185.63 \\
\hline
\end{tabular}

$* \& * *$ significant at $5 \%$ and $1 \%$ level of significance respectively 
Table.2 Genetic parameters of variability for yield and yield attributing characters in twenty nine genotypes of field bean

\begin{tabular}{|c|c|c|c|c|c|c|c|c|c|c|c|}
\hline \multirow{2}{*}{$\begin{array}{l}\text { S. } \\
\text { No. }\end{array}$} & \multirow[t]{2}{*}{ Character } & \multicolumn{2}{|c|}{ Range } & \multirow[t]{2}{*}{ Mean } & \multicolumn{2}{|c|}{ Variance } & \multicolumn{2}{|c|}{ Co efficient of variation } & \multirow{2}{*}{$\begin{array}{c}\text { Heritability } \\
\mathbf{h}^{2}(\%)\end{array}$} & \multirow{2}{*}{$\begin{array}{c}\text { Genetic } \\
\text { Advance }\end{array}$} & \multirow{2}{*}{$\begin{array}{c}\text { GA as per } \\
\text { cent of } \\
\text { mean }\end{array}$} \\
\hline & & Min. & Max. & & Phenotypic & Genotypic & $\operatorname{PCV}(\%)$ & GCV $(\%)$ & & & \\
\hline $\mathbf{1}$ & Days to first flowering & 46.30 & 85.43 & 70.54 & 69.85 & 66.46 & 11.853 & 11.562 & 95.15 & 16.39 & 23.23 \\
\hline 2 & Days to 50 per cent flowering & 51.50 & 92.67 & 73.66 & 75.29 & 71.46 & 11.779 & 11.472 & 94.86 & 16.95 & 23.02 \\
\hline 3 & Days to first pod set & 53.29 & 98.00 & 80.55 & 79.88 & 75.42 & 11.097 & 10.783 & 94.43 & 17.39 & 21.59 \\
\hline 4 & $\begin{array}{l}\text { No. of inflorescences per } \\
\text { plant }\end{array}$ & 11.90 & 28.40 & 21.22 & 18.15 & 17.75 & 20.068 & 19.848 & 97.82 & 8.58 & 40.44 \\
\hline 5 & Length of inflorescence $(\mathrm{cm})$ & 17.87 & 38.90 & 26.25 & 32.88 & 32.32 & 21.853 & 21.665 & 98.29 & 11.6 & 44.25 \\
\hline 6 & No. of pods per inflorescence & 3.08 & 10.83 & 7.07 & 4.05 & 4.02 & 28.421 & 28.297 & 99.13 & 4.1 & 58.04 \\
\hline 7 & Length of the pod $(\mathrm{cm})$ & 4.69 & 12.98 & 5.92 & 3.68 & 3.64 & 32.336 & 32.159 & 98.9 & 3.91 & 65.89 \\
\hline 8 & Width of the pod $(\mathrm{cm})$ & 1.25 & 2.32 & 1.86 & 0.06 & 0.05 & 12.565 & 12.268 & 95.33 & 0.458 & 24.67 \\
\hline 9 & Days to first pod harvest & 72.00 & 118.88 & 97.71 & 90.05 & 83.96 & 9.708 & 9.374 & 93.23 & 18.21 & 18.65 \\
\hline 10 & Days to last pod harvest & 101.00 & 185.63 & 156.47 & 394.29 & 379.07 & 12.69 & 12.443 & 96.14 & 39.32 & 25.13 \\
\hline 11 & Weight of 10 green pods (g) & 24.40 & 74.37 & 33.44 & 124.61 & 123.60 & 33.363 & 33.228 & 99.19 & 22.8 & 68.17 \\
\hline 12 & Number of pods per plant & 27.72 & 243.67 & 133.71 & 3077.09 & 3058.42 & 41.484 & 41.359 & 99.4 & 113.57 & 84.94 \\
\hline 13 & No. of seeds per pod & 3.42 & 5.26 & 3.89 & 0.17 & 0.16 & 10.582 & 10.268 & 94.16 & 0.80 & 20.53 \\
\hline 14 & Seed length $(\mathrm{mm})$ & 8.89 & 13.18 & 10.71 & 1.51 & 0.62 & 11.482 & 7.319 & 40.64 & 1.03 & 9.61 \\
\hline 15 & Seed width $(\mathrm{mm})$ & 6.17 & 9.61 & 7.39 & 0.74 & 0.17 & 11.636 & 5.631 & 23.42 & 0.415 & 5.61 \\
\hline 16 & Dry seed yield per plant (g) & 41.45 & 209.48 & 121.72 & 1836.41 & 1730.09 & 35.208 & 34.174 & 94.2 & 83.17 & 68.33 \\
\hline 17 & 100 seed weight (g) & 16.05 & 37.93 & 24.8 & 15.43 & 15.03 & 15.849 & 15.641 & 97.4 & 7.89 & 31.8 \\
\hline 18 & Fresh pod yield per plant (g) & 136.92 & 701.04 & 370.92 & 29273.25 & 29087.62 & 46.126 & 45.979 & 99.37 & 350.2 & 94.42 \\
\hline
\end{tabular}


The degree of variability shown by different parameters can be judged by the magnitude of genotypic coefficient of variation (GCV) and phenotypic coefficient of variation (PCV) (Table 3).

Close relationship between $\mathrm{GCV}$ and $\mathrm{PCV}$ was found in all the characters and PCV values were slightly greater than GCV indicating a very little influence of environment for their expression (Table 2). This is in confirmation with the results reported by Ganesh (2005), Lal et al., (2005), Bhuvaneshwari (2008), Rai et al., (2008), Savitha (2008), Upadhyay and Mehta (2010), Chaitanya et al., (2013) and Verma et al., (2015).

All the growth parameters, flower attributes, earliness attributes and pod and seed attributes except seed length and seed width had high genetic advance as per cent of mean coupled with high heritability estimates, indicating that these traits were under the strong influence of additive gene action and hence simple selection based on phenotypic performance of these traits would be more effective (Table 2).

Similar kind of results have been reported in field bean by Gupta and Samanta (1991), Borah and Shadeque (1992), Uddin and Newaz (1997), Savitha (2008), Mishra et al., (2008), Rai et al., (2009), Upadhyay and Mehta (2010) and Verma et al., (2015).

High heritability and moderate GA as per cent mean values were observed for the characters viz., days to first pod harvest, protein content and crude fibre content in seed (Table 2). This indicates the influence of non-additive gene action and considerable influence of environment on the expression of these traits. These traits could be exploited through manifestation of dominance and epistatic components through heterosis breeding.

\section{References}

Allard, R.W., 1960. Principles of Plant Breeding. John Wiley and Sons Inc, New York, USA. pp. 485.

Baswana, K.S., Pandita, M.L., Dhankhar B.S and Pratap B.S. 1980. Correlation and path coefficient analysis in Indian bean (Dolichos lablab var. lignosus L.). Haryana Agricultural University Journal of Research. 10 (4): 489-95.

Bhuvaneshwari (2008). Assessment of genetic diversity in local collections of field bean (Lablab purpureus L. Sweet). M.Sc. (Agri.) Thesis. UAS, Dharwad, Karnataka.

Borah, P and Shadeque, A. 1992. Studies on genetic variability of common dolichos bean. Indian Journal of Horticulture. 49 (3): 270-73.

Burton, G.W and Devane, E.M. 1953. Estimating heritability from replicated clonal material. Agronomy Journal. 45: 478-81.

Chaitanya, V., Reddy, R.V.S.K., Pandravada, S.R and Sujatha, M. 2013. Genetic divergence in dolichos bean (Dolichos lablab L. Var. Typicusprain) genotypes for yield and yield contributing traits. Electronic Journal Of Plant Breeding. 4 (4): 1340-43.

Chattopadyay, A and Dutta, S. 2010. Characterization and identification of selection indices of pole type dolichos bean. Vegetable Crops Research Bulletin. 73: 33-45.

Ganesh, B.N. 2005. Genetic variability and divergence studies by D2 statistics and RAPD analysis in field bean (Lablab purpureus L. Sweet). M. Sc. (Agri.) Thesis, Acharya N. G. Ranga Agril. Uni. S.V.Agri. College, Tirupati.

Gupta, S.K and Samanta, S.K. 1991. Genetic variability for green pod yield and other characters in Lablab bean. 
Agricultural Science Digest. 11 (2): 95-99.

Kambale, S.P., Harer, P.N., Lad, D.B., Bhor, T.J and Bangar, N.D. 2002. Genetic variability and heritability studies in wal (Lablab purpureus (L.) Sweet var. typicus

:/; ). Journal of Maharashtra Agricultural Universities. 27 (1): 119-20.

Lal, H., Rai, M., Verma, A and Vishwanath. 2005. Analysis of genetic divergence of dolichos bean (Lablab purpureus) genotypes. Vegetable Science. 32 (2): 129-32.

Lush, J.L. 1940. Intra-sire correlation on regression off-spring on dams as a method of estimating heritability of characters. Proceedings of American Society of Animal Production. 33: 292-01.

Mishra, S., Kumar, M and Sahu, G.S. 2008. Relationships among yield contributing characters in pole type French bean (Phaseolus vulgaris L.). The Orissa Journal of Horticulture. 36 (2): 108-13.

Panse, V.G. and Sukhatme, P.V. 1967. Statistical methods for Agricultural Workers, 2 nd Edition ICAR, New Delhi. pp. 324.

Patil, S.B and Lad, D.B. 2007. Variability studies in Wal (Lablab purpureus (L.) Sweet). Journal of Maharashtra
Agricultural Universities. 32 (2): 29697.

Rai, N., Asati, B.S and Singh, A.K. 2009. Genetic divergence in Indian bean. Legume Research. 32 (2): 166-72.

Rai, N., Singh, P.K., Verma, A., Lal, H., Yadav, D.S and Rai, M. 2008. Multivariate characterization of Indian Bean (Lablab purpureus (L.) Sweet.). Genotypes. Journal of Plant Genetic Resources. 21 (1): 42-45.

Savitha, B.N. 2008. Characterization of Avare (Lablab purpureus L. Sweet) local collections for genetic variability. M.Sc. (Agri.) Thesis. University of Agricultural Sciences, Dharwad.

Uddin, M.S and Newaz, M.A. 1997. Genetic parameters and the association among flower and pod characters of hyacinth bean (Lablab purpureus L.). Legume Research. 20 (2): 82-86.

Upadhyay and Mehta, N. 2010. Biometrical studies in Dolichos Bean (Dolichos lablab L.) for Chattisgarh Plains. Research Journal of Agricultural Sciences. 1 (4): 441-47.

Verma, A.K., Uma Jyothi, K and DorajeeRao, A.V.D. 2015. Variability and character association studies in dolichos bean (Lablab purpureus L.) Genotypes. Indian Journal of Agriculture Research. 49 (1): 46-52.

\section{How to cite this article:}

Sadak Peer, S., P. Syam Sundar Reddy, Syed Sadarunnisa, D.S. Reddy and Pandravada, S.R. 2018. Genetic Variability and Heritability for Yield and Yield Attributes in Field Bean (Lablab purpureus L.) Genotypes. Int.J.Curr.Microbiol.App.Sci. 7(03): 2131-2137. doi: https://doi.org/10.20546/ijcmas.2018.703.250 